\title{
EVALUATION OF TESTOSTERONE DEFICIENCY IN PATIENTS OF TYPE 2 DIABETES MELLITUS
}

\author{
Kuldeep Chandel1 ${ }^{1}$ Archit Gupta², Pallavi Agrawal ${ }^{3}$, Kshitiz Nath ${ }^{4}$
}

${ }^{1}$ Assistant Professor, Department of Medicine, MLB. Medical College, Jhansi.

${ }^{2}$ Senior Resident, Department of Medicine, MLB. Medical College, Jhansi.

${ }^{3}$ Assistant Professor, Department of Pathology, MLB. Medical College, Jhansi.

${ }^{4}$ Senior Resident, Department of Medicine, MLB. Medical College, Jhansi.

\section{ABSTRACT}

\section{BACKGROUND}

A high prevalence of low testosterone levels along with the conventional risk factors for diabetes mellitus type 2 have emerged in studies conducted worldwide. Thus, the purpose of the present study is to evaluate the relationship between type 2 DM and serum testosterone levels.

\section{MATERIAL AND METHODS}

The study was conducted in Department of Medicine, MLB. Medical College, Jhansi over the period of 2 years (2012-2014). A total of 160 diabetic patients and 80 controls were randomly selected from diabetic \& medicine OPD/IPD/ICU. After taking informed consent, history and examination, free and total testosterone levels were sent after overnight fasting. Data of cases were compared to that of controls using student ' $t$ ' test and $p$ value $<0.05$ was considered to be significant.

\section{RESULTS}

The study showed that testosterone deficiency was more prevalent in diabetic subjects in comparison to controls. Free testosterone levels were more significant in terms of difference of means between study and control groups $(\mathrm{p}<0.007)$.

\section{CONCLUSIONS}

With the results based on the study carried out, we concluded that testosterone deficiency was associated with Type 2 Diabetes Mellitus. Also the study showed that free testosterone level is more affected than total testosterone level in Type 2 Diabetes patients.

\section{KEYWORDS}

Testosterone, Hypogonadism, Diabetes Mellitus.

HOW TO CITE THIS ARTICLE: Chandel K, Gupta A, Agrawal P, et al. Evaluation of testosterone deficiency in patients of type 2 diabetes mellitus. J. Evolution Med. Dent. Sci. 2016;5(25):1317-1318, DOI: 10.14260/jemds/2016/309

\section{INTRODUCTION}

Diabetes is the single most important metabolic disease, which can affect nearly every organ system in the body. The worldwide prevalence of diabetes mellitus has risen dramatically over the past two decades. Based on current trend, the International Diabetes Federation projects that 438 million individuals will have diabetes by the year 2030 . Although, the prevalence of both type 1 and type $2 \mathrm{DM}$ is increasing worldwide, the prevalence of type $2 \mathrm{DM}$ is rising much more rapidly, presumably because of increasing obesity, reduced activity levels as countries become more industrialized and the aging of the population. ${ }^{1}$

Epidemiological studies have reported that diabetes is an independent risk factor for low testosterone levels. Interestingly, concentrations of free and bioavailable testosterone even in the low-normal range are associated with diabetes after adjusting for adiposity. The prevalence of both hypogonadism and Diabetes Mellitus (DM) increase with age, and the association between these conditions has recently received great attention.

Some authors suggest that at physiological levels, testosterone has a role in maintaining normal insulin

Financial or Other, Competing Interest: None.

Submission 12-02-2016, Peer Review 09-03-2016,

Acceptance 14-03-2016, Published 25-03-2016.

Corresponding Author:

Dr. Kuldeep Chandel,

Department of Medicine,

M.L.B. Medical College,

Jhansi.

E-mail: kuldeepchandel@rediffmail.com

DOI: $10.14260 /$ jemds/2016/309 sensitivity in men, an effect that is lost at low or high concentrations. $^{2}$ Other studies have shown that administration of testosterone to hypogonadal middle-aged men improves insulin sensitivity and glucose homeostasis. ${ }^{3}$

Thus, the present study was conducted to find out the relationship between type $2 \mathrm{DM}$ and testosterone deficiency in patients with type 2 diabetes, as the benefits of identifying at an early stage and even in asymptomatic patients is considerable.

\section{MATERIAL AND METHODS}

This case control study was conducted in Department of Medicine, M.L.B. Medical College and Hospital, Jhansi, in patients with type 2 diabetes mellitus over the period of 2 years (2012-2014). A total of 160 diabetic patients and 80 controls were studied. Informed consent was taken from all the subjects. Each patient was then subjected to detailed history and clinical examination including age, sex and duration of diabetes and existence of complications of diabetes, history of diabetic medication. Anthropometric indices measured were weight, height, body mass index, waist hip ratio, while the clinical indices measured were pulse rate, JVP and blood pressure. All routine investigations were done.

All the patients with type 2 diabetes with age more than 30 years were included in the study. Patient with other comorbid conditions, patients taking medication which interfere with testosterone levels, patients with features of congenital GnRH deficiency were excluded from the study. The patient was then subjected to specific investigation (Free and total testosterone) after an overnight fast using Chemiluminescent Immunoassay. 
The data collected from cases and controls were compared statistically by student ' $t$ ' test and $p$ value $<0.05$ was considered to be significant.

\section{OBSERVATION AND RESULTS}

In the present study, total 160 patients of diabetes mellitus and 80 healthy controls of age between 30-70 years were evaluated. The mean age in the present study was $52.45 \pm 12.05$ in case group and $53.64 \pm 11.16$ in control group. Majority of the cases (40.1\%) and controls (37.5\%) were in age groups of 51-60 years. The male:female ratio in cases was $2: 1$ and in controls was 1.7:1. The systolic and diastolic blood pressure of both cases and controls were comparable without any significant difference, but BMI of diabetics $(23.645 \pm 3.01)$ was significantly higher than of controls $(22.16 \pm 1.52)$ with $p$ value $=0.02$ (Table 1$)$.

\begin{tabular}{|c|c|c|c|}
\hline Parameters & Case & Control Group & p-value \\
\hline $\begin{array}{c}\text { SBP }(\mathbf{m m H g}) \\
\text { Range } \\
\text { Median } \\
\text { Mean } \pm \text { SD }\end{array}$ & $\begin{array}{c}118-210 \\
134 \\
137.42 \pm 15.3\end{array}$ & $\begin{array}{c}112-186 \\
134 \\
138.8 \pm 14.76\end{array}$ & 0.50 \\
\hline $\begin{array}{c}\text { DBP }(\mathbf{m m H g}) \\
\text { Range } \\
\text { Median } \\
\text { Mean } \pm \text { SD }\end{array}$ & $\begin{array}{c}74-108 \\
86 \\
86.96 \pm 5.76\end{array}$ & $\begin{array}{c}76-110 \\
88 \\
88.17 \pm 6.56\end{array}$ & 0.16 \\
\hline $\begin{array}{c}\text { BMI } \\
\text { Range } \\
\text { Median } \\
\text { Mean } \pm \text { SD }\end{array}$ & $\begin{array}{c}18.4-29.7 \\
22.9 \\
23.645 \pm 3.01\end{array}$ & $\begin{array}{c}17.9-28.7 \\
21.9 \\
22.16 \pm 1.52\end{array}$ & 0.02 \\
\hline $\begin{array}{c}\text { Waist-Hip Ratio } \\
\text { Range } \\
\text { Median } \\
\text { Mean } \pm \text { SD }\end{array}$ & $\begin{array}{c}0.6-1.5 \\
0.91 \\
0.92 \pm 0.10\end{array}$ & $\begin{array}{c}0.72-1.45 \\
0.9 \\
0.89 \pm 0.06\end{array}$ & 0.01 \\
\hline
\end{tabular}

In our study, the levels of serum lipids were found to be elevated in diabetic patients. Triglycerides level showed the strongest difference in between the two groups with a p-value of $<0.001$ (Table 2).

\begin{tabular}{|c|c|c|c|}
\hline Lipid Profile & Cases & Controls & $\begin{array}{c}\text { P- } \\
\text { value }\end{array}$ \\
\hline $\begin{array}{c}\text { Triglyceride } \\
\text { (mg/dL) } \\
\text { Range } \\
\text { Median } \\
\text { Mean } \pm \text { SD } \\
\end{array}$ & $\begin{array}{c}95-299 \\
142 \\
145.26 \pm 33.63\end{array}$ & $\begin{array}{c}95-189 \\
128 \\
130.66 \pm 14.95 \\
\end{array}$ & $\begin{array}{c}< \\
.0001\end{array}$ \\
\hline $\begin{array}{c}\text { Total Cholesterol } \\
\text { (mg/dL) } \\
\text { Range } \\
\text { Median } \\
\text { Mean } \pm \text { SD }\end{array}$ & $\begin{array}{c}147-316 \\
207 \\
213.8 \pm 29.18\end{array}$ & $\begin{array}{c}144-288 \\
195 \\
198.61 \pm 24.75 \\
\end{array}$ & . 012. \\
\hline $\begin{array}{l}\text { HDL Cholesterol } \\
\text { (mg/dL) } \\
\text { Range } \\
\text { Median } \\
\text { Mean } \pm \text { SD } \\
\end{array}$ & $\begin{array}{c}42-74 \\
58 \\
59.04 \pm 5.92 \\
\end{array}$ & $\begin{array}{c}36-76 \\
62 \\
61.125 \pm 6.4 \\
\end{array}$ & .0167 \\
\hline $\begin{array}{c}\text { LDL Cholesterol } \\
\text { (mg/dL) } \\
\text { Range } \\
\text { Median } \\
\text { Mean } \pm \text { SD }\end{array}$ & $\begin{array}{c}72-162 \\
110 \\
113 \pm 15.5\end{array}$ & $\begin{array}{c}68-132 \\
100.5 \\
101.16 \pm 14.54\end{array}$ & $\begin{array}{c}< \\
.0001\end{array}$ \\
\hline Table 2: Com & f Lipid Pro & in Cases \& Cont & \\
\hline
\end{tabular}

The mean fasting blood sugar and random blood sugar among cases and controls are given in Table 3. Cases have higher fasting and random blood sugar as compared to controls.

\begin{tabular}{|c|c|c|c|}
\hline Parameters & Cases & Controls & $\begin{array}{c}\text { p- } \\
\text { value }\end{array}$ \\
\hline $\begin{array}{c}\text { FBS (mg\%) } \\
\text { Range }\end{array}$ & $87-167$ & $78-121$ & \\
Median & 131 & 104 & 0.0001 \\
Mean \pm SD & $130.56 \pm 18.41$ & $102.68 \pm 10.07$ & \\
\hline $\begin{array}{c}\text { RBS (mg\%) } \\
\text { Range }\end{array}$ & $98-301$ & $119-198$ & 0.0001 \\
Median & 213 & 167 & \\
Mean \pm SD & $210.93 \pm 29.23$ & $162.89 \pm 24.59$ & \\
\hline \multicolumn{3}{|c|}{ Table 3: Fasting and Random Blood } \\
Sugar in Cases and Controls \\
\hline \multicolumn{3}{|c}{} \\
\hline
\end{tabular}

Out of 160 cases, 22 subjects have low serum total testosterone and 32 have low free testosterone. Out of 80 controls, 7 were having low total testosterone and 8 were having low free testosterone (Table 4).

\begin{tabular}{|c|c|c|c|c|}
\hline \multirow{2}{*}{$\begin{array}{c}\text { Serum } \\
\text { Testosterone }\end{array}$} & \multicolumn{2}{|c|}{$\begin{array}{c}\text { Cases } \\
(\mathbf{N = 1 6 0 )}\end{array}$} & \multicolumn{2}{c|}{$\begin{array}{c}\text { Controls } \\
(\mathbf{N = 8 0})\end{array}$} \\
\cline { 2 - 5 } & No. & $\mathbf{\%}$ & No. & $\mathbf{\%}$ \\
\hline Total testosterone & 22 & 13.75 & 7 & 8.75 \\
\hline Free testosterone & 32 & 20 & 8 & 10 \\
\hline Table 4: Distribution of Low Serum Testosterone Level \\
in Cases and Controls \\
\hline
\end{tabular}

On grouping cases with low testosterone level according to their duration of diabetes, it was found that testosterone level both total and free was decreasing as the duration of diabetes of the subjects was increasing. Maximum prevalence of decreased testosterone level, both total and free was found in diabetics with duration of diabetes $>10$ years and minimum was present with duration of diabetes $<5$ years; $20 \%$ of the diabetics with duration of diabetes $>10$ years were found to have low total testosterone and $22.5 \%$ were having low free testosterone (Table 5).

\begin{tabular}{|c|c|c|c|c|}
\hline $\begin{array}{c}\text { Duration of } \\
\text { Diabetes } \\
\text { (Years) }\end{array}$ & \multicolumn{2}{|c|}{$\begin{array}{c}\text { Low Total } \\
\text { Testosterone }\end{array}$} & \multicolumn{2}{c|}{$\begin{array}{c}\text { Low Free } \\
\text { Testosterone }\end{array}$} \\
\cline { 2 - 5 } $\mathbf{N}$ & $\mathbf{\%}$ & $\mathbf{N}$ & $\%$ \\
\hline$<5(\mathrm{n}=28)$ & 1 & 3.57 & 4 & 14.28 \\
\hline $5-10(\mathrm{n}=92)$ & 13 & 14.13 & 19 & 20.65 \\
\hline$>10(\mathrm{n}=40)$ & 8 & 20 & 9 & 22.5 \\
\hline \multicolumn{3}{|c|}{} \\
Table 5: Correlation between Testosterone Level and \\
Duration of Diabetes
\end{tabular}

In our study the difference in mean total testosterone between cases (272.9) and controls (307.03) was not significant $(\mathrm{P}=0.23)$, but mean free testosterone was significantly abnormal in diabetes group (91.16) in comparison with control group (121.93) $(\mathrm{P}=0.007)$ (Table 6).

\begin{tabular}{|c|c|c|c|}
\hline Testosterone Level & Cases & Controls & P-value \\
\hline Total Testosterone & & & \\
Range & $4.5-1008$ & $5.2-986.5$ & 0.23 \\
Median & 316.5 & 365.1 & \\
Mean \pm SD & $272.9 \pm 195.9$ & $307.03 \pm 236.2$ & \\
Free Testosterone & & & \\
Range & $1.5-289$ & $2.5-288$ & 0.007 \\
Median & 77.9 & 150.85 & \\
Mean \pm SD & $91.16 \pm 74.58$ & $121.93 \pm 97.54$ & \\
\hline \multicolumn{4}{|c|}{ Table 6: Comparison of Testosterone Level in Cases \& Controls } \\
\hline
\end{tabular}

\section{DISCUSSION}

The prevalence of both hypogonadism and Diabetes Mellitus (DM) increases with age and the association between these conditions have recently received great attention. The Massachusetts Male Aging Study prospectively found that for each decrease of 1 SD in Free Testosterone (FT), there was a 1.58-fold greater risk of developing DM after a median interval of 8.9 years. 4 
Testosterone Deficiency Syndrome (TDS) and symptomatic hypogonadism is an entity characterized by clinical symptoms and biochemical parameters of testosterone deficiency. ${ }^{5}$ The prevalence rate of symptomatic hypogonadism in men with type $2 \mathrm{DM}$ is high and documented rates range from $20-64 \%$ with higher prevalence rates reported in the elderly.

The mechanisms underlying hypogonadotropic hypogonadism in men with type 2 diabetes are not clear. It has been suggested that an excessive increase in fat mass may result in an increase in the activity of aromatase enzyme, which causes greater conversion of testosterone into oestrogen (The primary female sex hormone). An increase in oestrogen levels would lead to the suppression of gonadotropin releasing hormone and impaired secretion of gonadotropin by the pituitary gland. This results in the reduction of both testosterone secretion and mature sperm production. The state of hypogonadotropic hypogonadism is not entirely dependent upon obesity. ${ }^{6}$ Based on animal studies and cell-culture experiments, it is becoming increasingly evident that the action of insulin and responsiveness to insulin in the brain are necessary for the adequate function of the hypothalamo-hypophyseal axis (Hypothalamus, pituitary gland, testes).

Thus, insensitivity to insulin at the hypothalamic level may contribute to the development of hypogonadotropic hypogonadism. Insensitivity to insulin is also associated with an increased concentration of inflammatory proteins in the blood. These proteins may also directly suppress the release of gonadotropin-releasing hormone from the hypothalamus. A meta-analysis by Ding et al. in $2006 .^{7}$ showed that men with diabetes had significantly lower levels of serum testosterone when compared with men without diabetes. The mean pooled difference between the two groups was $-76.6 \mathrm{ng} / \mathrm{dL}(95 \%$ confidence interval-99.4 to $-53.6 \mathrm{ng} / \mathrm{dL}$ ). They also found that men with higher total testosterone concentrations (449.6$605.2 \mathrm{ng} / \mathrm{dL}$ ) had a $42 \%$ lower risk of type 2 diabetes than those with lower concentrations (213.2-446.7 ng/dL).

Another meta-analysis by Corona et al. ${ }^{8}$ similarly showed that men who had lower baseline total testosterone had an increased incidence of incident diabetes in comparison with controls. In the Third National Health and Nutrition Examination Survey. ${ }^{9}$ the investigators studied a cohort of 1,413 adult men, 101 of whom had diabetes and found that men in the lowest percentile of free testosterone had an approximately four-fold increased risk of having diabetes when compared with men in the highest percentile of free testosterone, even after adjustment for age, ethnicity and adiposity.

In another cross-sectional study of 1,292 men by Brand et al.10 it was shown that diabetic men had not only lower testosterone, but also lower levels of Sex Hormone Binding Globulin (SHBG) when compared with non-diabetic men. In another cross-sectional survey of 574 men with type 2 diabetes and 69 men with type 1 diabetes by Grossmann et al. ${ }^{11}$ testosterone deficiency was found to be more common in men with diabetes regardless of type of diabetes.

The Hypogonadism in males study of 1,849 men $(1,451$ non-diabetic and 398 diabetic) showed that testosterone levels were also influenced by the presence of obesity in the study subjects, as they found a negative correlation between testosterone and body mass index irrespective of whether the subjects had diabetes or not, although diabetic men had a higher prevalence of low free testosterone across all body mass index categories. ${ }^{12}$
Our study is well in concordance with the above studies showing lower levels of testosterone in diabetic patients. Also in our study, free testosterone was significantly reduced as compared to that of controls. BMI of our study group was higher than that of controls, which was statistically significant suggesting that obese patients do have lower levels of testosterone. However, testosterone therapy for the patients with lower hormone levels needs further study to examine the risk of a variety of specific serious adverse cardiovascular events in relation to testosterone dose and duration and to assess if the risks of testosterone therapy vary by level of serum testosterone and presence or absence of hypogonadal disease.

\section{CONCLUSION}

We concluded that testosterone deficiency was found to be more prevalent in diabetic subjects than in controls. Free testosterone was significantly more decreased than total testosterone and both total and free testosterone was significantly decreased in diabetics. As evident by our study, we suggest that routine testing of testosterone levels in all diabetics will be beneficial and should be recommended.

\section{REFERENCES}

1. Powers AC. Diabetes mellitus harrison's principles of internal medicine. McGraw-Hill, 18th edition, 2012;2(344):2968-3003.

2. Livingstone $C$, Collison $M$. Sex steroids and insulin resistance. Clin Sci (Lond) 2002;102(2):151-66.

3. Boyanov MA, Boneva Z, Christov VG. Testosterone supplementation in men with type 2 diabetes, visceral obesity and partial androgen deficiency. Aging Male 2003;6(1):1-7.

4. Stellato RK, Feldman HA, Hamdy O, et al. Testosterone, sex hormone-binding globulin, and the development of type 2 diabetes in middle-aged men: prospective results from the massachusetts male aging study. Diabetes Care 2000;23(4):490-4.

5. Galloway M. Testosterone deficiency syndrome: a common factor in type 2 diabetes and erectile dysfunction patients. Prac Diab Int 2008;25:3-10.

6. Marin P, Holmang S, Jonsson L, et al. The effects of testosterone treatment on body composition and metabolism in middle-aged obese men. Int J Obes Relat Metab Disord 1992;16(12):991-7.

7. Ding EL, Song Y, Malik VS, et al. Sex differences of endogenous sex hormones and risk of type 2 diabetes: a systematic review and meta-analysis. JAMA 2006;295:1288-1299.

8. Corona G, Monami M, Rastrelli G, et al. Type 2 diabetes mellitus and testosterone: a meta-analysis study. Int J Androl 2011;34(6 Pt 1):528-540.

9. Selvin E, Feinleib M, Zhang L, et al. Androgens and diabetes in men: results from the third national health and nutrition examination survey (NHANES III). Diabetes Care 2007;30(2):234-238.

10. Brand JS, Wareham NJ, Dowsett M, et al. Associations of endogenous testosterone and SHBG with glycated haemoglobin in middle-aged and older men. Clin Endocrinol (Oxf) 2011;74(5):572-578.

11. Grossmann M, Thomas MC, Panagiotopoulos S, et al. Low testosterone levels are common and associated with insulin resistance in men with diabetes. J Clin Endocrinol Metab 2008;93(5):1834-1840.

12. Mulligan T, Frick MF, Zuraw QC, et al. Prevalence of hypogonadism in males aged at least 45 years: the HIM study. Int J Clin Pract 2006;60(7):762-769. 